\title{
Levalbuterol Tartrate
}

National Cancer Institute

\section{Source}

National Cancer Institute. Levalbuterol Tartrate. NCI Thesaurus. Code C66003.

The tartrate salt form of levalbuterol, the R-enantiomer of the short-acting beta-2 adrenergic receptor agonist albuterol, with bronchodilator activity. Levalbuterol selectively binds to beta- 2 adrenergic receptors in bronchial smooth muscle, thereby activating intracellular adenyl cyclase, an enzyme that catalyzes the conversion of adenosine triphosphate (ATP) to cyclic-3',5'-adenosine monophosphate (CAMP). Increased cAMP levels cause relaxation of bronchial smooth muscle, relieve bronchospasms, improve mucociliary clearance and inhibit the release of mediators of immediate hypersensitivity from cells, especially from mast cells. 